\title{
MOTIVASI MENGIKUTI PEMBELAJARAN PJOK PESERTA DIDIK SMA DI KECAMATAN BANGLI DALAM PEMBELAJARAN DARING
}

\author{
I Nengah Wiraguna', I Gusti Lanang Agung Parwata², I Ketut Semarayasa ${ }^{3}$ \\ ${ }^{123}$ Prodi Pendidikan Jasmani Kesehatan dan Rekreasi \\ Jurusan Pendidikan Olahraga \\ Fakultas Olahraga dan Kesehatan \\ Universitas Pendidikan Ganesha \\ Email : nengahwrg@gmail.com1, agung.parwata@undiksha.ac.id2, \\ ketut.semarayasa@undiksha.ac.id3
}

\begin{abstract}
ABSTRAK
Penelitian ini bertujuan untuk mengetahui motivasi mengikuti pembelajaran PJOK peserta didik SMA di Kecamatan Bangli dalam pembelajaran daring. Penelitian ini merupakan penelitian deskriptif kuantitatif dengan metode survei. Populasi dalam penelitian ini adalah peserta didik SMA di Kecamatan Bangli. Sampel ditentukan dengan menggunakan teknik random sampling. Data dianalisis menggunakan teknik statistik dengan presentase. Hasil dari analisis data, didapatkan bahwa motivasi peserta didik mengikuti pembelajaran PJOK di SMA Negeri 1 Bangli berada pada kategori sangat tinggi dengan persentase sebesar $31,09 \%$. Sedangkan pada peserta didik SMA Negeri 2 Bangli motivasi peserta didik berada pada kategori sangat tinggi dengan persentase sebesar $37,50 \%$. Dari hasil analisis secara keseluruhan, motivasi peserta didik adalah sebesar $41,18 \%$ dengan kategori motivasi sangat tinggi. Dari data motivasi yang telah dianalisis, hasil penelitian menunjukan bahwa motivasi mengikuti pembelajaran PJOK peserta didik SMA di Kecamatan Bangli dalam pembelajaran daring berada dalam kategori sangat tinggi.
\end{abstract}

Kata Kunci: Motivasi, PJOK, pembelajaran daring

\begin{abstract}
The aimed of this study was to know the motivation attending PJOK course students in SMA Bangli district through online learning process. this study was descriptive quantitative with the survey method used. The population of this study was the students in SMA Bangli district. The sample chosen with random sampling technique. The data analysis used statistic technique with percentages. The result of this study showed that the students motivation attending the PJOK course in SMA Negeri 1 Bangli are in very high category percentage by $31,09 \%$. Meanwhile the students motivation in SMA Negeri 2 Bangli are in very high category by $37,50 \%$. From the whole analysis, the students motivation are $41,18 \%$ with very high motivation category. From the motivation data analysis, the result of study showed that the motivation attending PJOK course students SMA Bangli district in online learning is in the very high category
\end{abstract}

Key word: Motivation, PJOK, Online Learning 


\section{PENDAHULUAN}

Pendidikan di sekolah tidak akan jauh dari namanya proses pembelajaran. Proses pembelajaran yaitu yang di dalamnya terjadi proses interaksi guru dengan peserta didik dan antara sesama peserta didik untuk mencapai suatu tujuan yaitu terjadi perubahan sikap dan tingkah laku peserta didik. Proses pembelajaran merupakan suatu hal yang bertujuan untuk mengembangkan kemampuan berkomunikasi yang baik, yang terjadi antara guru dan sesama peserta didik yang dilandasi sikap saling menghargai secara terus menerus dikembangkan didalam kegiatan belajar mengajar. Menurut Roesminingsih dan Susarno (dalam David Havera Ariffudin, 2016:130) Pendidikan pada hakikatnya akan mencakup kegiatan mendidik, mengajar dan melatih. Kegiatan tersebut kita laksanakan sebagai suatu usaha untuk mentrasformasikan nilai-nilai. Maka dalam pelaksanaanya harus serempak, terpadu dan berkelanjutan, serta serasi dengan perkembangan anak didik serta lingkungan hidupnya.

Pada dasarnya setiap peserta didik memiliki cara yang berbeda untuk memahami mengenai materi-materi yang diberikan oleh guru, dalam proses pembelajaran Pendidikan Jasmani, Olahraga dan Kesehatan (PJOK) guru dituntut mampu memberikan variasi dan inovasi dalam pembelajaran dan mampu untuk meningkatkan motivasi belajar peserta didik yang bertujuan agar peserta didik memahami materi yang akan diajarkan sehingga peserta didik dapat mencapai keberhasilan dan lebih aktif dalam proses pembelajaran.

Belajar merupakan kegiatan yang dapat dilakukan oleh semua orang, baik itu belajar di sekolah atau di rumah, itu semua dapat dikatakan sebagai kegiatan belajar. Di sekolah, kegiatan belajar adalah kegiatan sehari-hari bagi peserta didik. Proses pembelajaran yang dilakukan peserta didik di sekolah tersebut merupakan suatu kegiatan belajar yang tergolong dirancang dalam desain instruksional atau dalam rancangan guru, dan memiliki tujuan untuk mengerjakan tugas-tugas belajar yang diberikan oleh guru di sekolah. Selain itu ada juga kegiatan belajar yang tidak termasuk dalam rancangan guru, yang berarti peserta didik itu belajar karena keinginannya sendiri atau adanya motivasi bagi peserta didik untuk belajar. Motivasi itu sendiri terdiri dari dalam diri dan dari luar diri. Dalam pembelajaran, motivasi setiap individu peserta didik sangatlah dibutuhkan untuk mengikuti proses belajar mengajar di sekolah, karena dengan adanya motivasi diharapkan setiap peserta didik memiliki keinginannya sendiri untuk mencapai suatu tujuan belajar.

Covid-19 adalah virus yang menyebar di seluruh dunia yang berawal dari negara China terjadi pada akhir tahun 2019. Di Indonesia virus ini mulai mewabah pada bulan februari 2020, dampak dari mewabahnya virus covid-19 di Indonesia menyebabkan proses pembelajaran di sekolah menjadi terganggu karena cepatnya penyebaran virus covid-19 ini. Untuk melingdungi warga sekolah, maka dari itu sistem pembelajaran di sekolah dialihkan menjadi pembelajaran dalam jaringan (daring).

Di berbagai daerah telah menerapkan proses pembelajaran daring untuk menunjang agar tetap berlangsungnya proses pembelajaran bagi peserta didik, SMA di Kemacamatan Bangli juga telah melaksanakan pembelajaran secara daring yang diakibatkan oleh Covid-19 ini. SMA di Kecamatan Bangli terdiri dari SMA Negeri 1 Bangli, dan SMA Negeri 2 Bangli. Dari hasil wawancara yang peneliti lakukan dengan guru PJOK di SMA Kecamatan Bangli berpendapat bahwa dalam proses pembelajaran daring, peserta didik serta guru perlu beradaptasi dengan cepat agar proses pembelajaran menjadi lebih efektif dalam proses pembelajaran PJOK secara 
daring dan tidak mengakibatkan peserta didik cepat bosan untuk mengikuti proses pembelajaran PJOK secara daring.

Pada dasarnya pembelajaran

Pendidikan Jasmani, Olahraga dan Kesehatan (PJOK) adalah suatu pembelajaran bagi peserta didik yang melibatkan aktivitas fisik dan dilaksanakan di lapangan terbuka, dengan mewabahnya Covid-19 ini maka proses pembelajaran PJOK menjadi terganggu. Oleh karena itu guru PJOK dituntut untuk mampu meningkatkan kualitas dari proses pembelajaran PJOK secara daring agar peserta didik bersemangat untuk mengikuti proses pembelajaran PJOK secara daring.

Berdasarkan dari latar belakang diatas, maka peneliti ingin mengadakan penelitian tentang "Motivasi Mengikuti Pembelajaran PJOK Peserta Didik SMA di Kecamatan Bangli dalam Pembelajaran Daring"..

\section{METODE PENELITIAN}

\begin{abstract}
Penelitian ini menggunakan metode penelitian deskriptif kuantitatif. Menurut I Nyoman Kanca (2010:57) penelitian deskriptif adalah penelitian yang bertujuan untuk mendeskripsikan secara sistematis, faktual dan akurat terhadap suatu populasi, atau daerah tertentu. Penelitian ini bertujuan untuk mengetahui motivasi peserta didik SMA di Kecamatan Bangli mengikuti pembelajaran PJOK dalam pembelajaran daring.
\end{abstract}

\section{Populasi Penelitian}

Dalam melakukan penelitian harus memiliki populasi dan sampel. Populasi menentukan sampel yang diambil, "populasi adalah keseluruhan atau himpunan objek dengan ciri yang sama" (kanca, 2010:19). Selain itu, populasi dapat diartikan sebagai totalitas dari semua objek atau individu yang memiliki karakteristik tertentu.
Dalam penelitian ini populasi penelitian mencakup seluruh peserta didik kelas X, XI, dan XII SMA di Kecamatan Bangli, kemudian di pilih kelas penelitian secara random dengan cara lotre.

\section{Sampel Penelitian}

Sampel adalah "himpunan bagian yang diambil secara representatif dari populasi" (Kanca, 2010:20). Dalam penentuan sampel penelitian menggunakan teknik sampel random sampling yaitu: digunakan apabila populasi homogen.

Menurut Suharsimi Arikunto (2014: 174) sampel adalah sebagian atau wakil dari populasi yang akan diteliti. Dimana untuk mengambil sambil sampel harus dilakukan dengan cara yang benar-benar berfungsi, sebagai contoh dan dapat menggambarkan keadaan populasi yang sebenarnya, dengan kata lain representatif (mewakili). Menurut Arikunto (dalam Anggreni) menyatakan apabila subjek kurang dari 100, maka lebih baik diambil semua sehingga diantara 10\%$15 \%$ atau 20\%-25\% atau lebih. Pengambilan sampel dilakukan dengan bantuan atau lotre.

Dari pendapat di atas, pengambilan sampel penelitian ini adalah $14,00 \%$ dari 850 populasi, yang berarti $14,00 \%$ / $100 \mathrm{X}$ $850=119$. Dari hasil tersebut maka sampel yang digunakan di SMA Negeri 1 Bangli sebanyak 119 peserta didik. Sedangkan pengambilan sampel di SMA Negeri 2 Bangli dalam penelitian ini adalah $18,00 \%$ dari 758 populasi, yang berarti $18,00 \% / 100 \times 758=136$. Dari hasil tersebut maka sampel penelitian di SMA Negeri 2 Bangli sebanyak 136 peserta didik. Dari hasil di atas, jumlah total sampel penelitian adalah 255 peserta didik SMA di Kecamatan Bangli. Pengambilan sampel menggunakan sample random sampling yang dilakukan secara acak menggunakan undian. 
Variabel Penelitian

Variabel penelitian dalam penelitian

ini adalah motivasi peserta didik mengikuti pembelajaran PJOK SMA di Kecamatan Bangli dalam pembelajaran daring.

\section{Metode Pengumpulan Data}

Tujuan yang utama dari penelitian ini adalah mendapatkan data yang sesuai dengan masalah penelitian. Data yang dianalisis harus dikumpulkan terlebih dahulu untuk mempermudah penelitian dan melakukan analisis data. Maka perlu metode pengumpulan data yang tepat agar data yang diperoleh juga tepat.

Metode dalam pengumpulan data pada penelitian ini ialah metode observasi, metode wawancara, dan metode angket/kuisioner. Sedangkan metode penunjang pengambilan data dalam penelitian ini ialah metode dokumentasi.

\section{a) Metode Observasi}

Dalam proses pengumpulan data, penelitian ini menggunakan metode observasi. Metode observasi merupakan metode yang berisi sebuah proses pengamatan yang dilakukan seorang peneliti untuk memperoleh pedoman yang digunakan untuk memperoleh data.

b) Metode Wawancara

Dalam proses pengumpulan data, penelitian ini menggunakan metode wawancara. Menurut sugiyono, (2006:19) ada dua pedoman dalam melakukan wawancara, yaitu wawancara terstruktur dan wawancara tidak terstruktur. Jenis wawancara yang digunakan dalam penelitin ini adalah wawancara tidak terstruktur.

c) Metode Angket/Kuisioner

Angket pada umumnya meminta keterangan tentang fakta yang diketahui oleh responden atau juga mengenai pendapat atau sikap. Angket ini digunakan untuk memperoleh data mengenai motivasi peserta didik dalam mengikuti pembelajaran Pendidikan Jasmani, Olahraga dan Kesehatan SMA di Kecamatan Bangli dalam pembelajaran daring.

d) Metode Dokumentasi

Dokumentasi merupakan kegiatan untuk menyimpan ataupun mengabadikan suatu peristiwa. Dalam penelitian ini metode dokumentasi digunakan untuk mengabadikan kegiatan penelitian mengenai motivasi peserta didik mengikuti pembelajaran PJOK dalam pembelajaran daring.

Instrumen Penelitian

Instrumen penelitian adalah alat yang digunakan peneliti untuk mengerjakan sesuatu lebih terarah dan sistematis. Menurut Wendra (2019:66) intrumen penelitian adalah alat yang sifatnya khusus lebih teknis dan oprasional untuk memperoleh data. Penentuan instrumen dalam penelitian ini berkaitan erat dengan metode pengumpulan data yang dipilih. Semua instrumen dalam penelitian ini disiapkan dan dirancang untuk mendapatkan data yang mendukung penelitian ini.

Dalam penelitian ini instrumen yang digunakan adalah angket/kuisioner yang berisi pertanyaan yang digunakan untuk mengetahui tingkat motivasi peserta didik mengikuti pembelajaran PJOK SMA di Kecamatan Bangli dalam pembelajaran daring yang ditinjau dari jenis-jenis motivasi yaitu dari dalam diri (pengetahuan, perhatian, minat), dan dari luar diri (guru, teman, sarana prasarana, orang tua). Menurut Suharsini Arikunto (2014:194) angket atau kuisioner adalah jumlah pernyataan yang tertulis yang digunakan untuk memperoleh informasi dari responden dalam arti laporan tentang pribadinya atau hal-hal yang diketahui.

\section{Teknik Analisis Data}

Teknik analisis yang digunakan adalah analisis data deskriptif dengan persentase, yaitu data dari angket yang berhasil dikumpulkan kemudian dianalisis 
dengan menggunakan persentase. Teknik analisis data yang digunakan dalam penelitian ini menggunakan teknik analisis data deskriptif, penghitungan statistic deskriptif menggunakan statistik persentase, karena yang termasuk dalam statistic deskriptif antara lain penyajian data melalui tabel, grafik, pictogram, perhitungan mean, modus, median, perhitugan penyebaran data perhitungan rata-rata, standar devisiasi, dan persentase. Pengkategorian menggunakan Mean dan Standar Devisiasi..

\section{HASIL DAN PEMBAHASAN}

\section{Deskripsi Umum Penelitian}

Penelitian ini dilakukan di SMA seKecamatan Bangli yakni SMA Negeri 1 Bangli dan SMA Negeri 2 Bangli, penelitian ini dilaksanakan dari tanggal 31 Agustus sampai tanggal 3 September 2020. Penelitian ini melibatkan seluruh peserta didik di SMA Negeri 1 Bangli dan SMA Negeri 2 Bangli, jumlah populasi dalam penelitian ini dari kedua sekolah yakni sebanyak 1.608 peserta didik yang terdiri dari 850 peserta didik di SMA Negeri 1 Bangli dan 758 peserta didik di SMA Negeri 2 Bangli. Dari 1.608 populasi peneliti mendapakan 255 sampel yang terbagi dalam dua sekolah yakni 119 peserta didik di SMA Negeri 1 Bangli dan 136 peserta didik di SMA Negeri 2 Bangli.

Pengambilan sampel dalam penelitian ini diambil di masing-masing angkatan di setiap sekolah, yakni pada
SMA Negeri 1 Bangli di kelas $X$ diperoleh 50 peserta didik, kelas XI 35 peserta didik dan di kelas XII 34 peserta didik. Untuk di SMA Negeri 2 Bangli di kelas $X$ terdiri dari 25 peserta didik, di kelas XI 51 peserta didik dan di kelas XII 60 peserta didik. Pengambilan data dalam penelitian ini dilaksanakan melalui penyebaran kuisioner dengan menggunakan bantuan google form dan link dari kuisioner tersebut disebarkan melalui grup belajar kelas di setiap sekolah.

\section{Deskripsi Hasil Analisis Data}

Variabel dalam penelitian ini adalah motivasi pada peserta didik SMA di Kecamatan Bangli dalam mengikuti pembelajaran PJOK dalam pembelajaran daring. Hasil dalam penelitian ini diperoleh melalui kuisioner yang diisi oleh setiap responden, untuk mempermudah dalam penyajian data maka data motivasi perlu di deskripsikan terlebih dahulu sebelum dianalisis. Faktor-faktor yang diamati terhadap motivasi peserta didik dalam pembelajaran Pendidikan Jasmani, Olahraga dan Kesehatan secara daring yaitu faktor intrinsik dan ekstrinsik yang terdiri dari indikator pengetahuan, perhatian, minat, guru, teman, sarana prasarana dan juga orang tua.

Hasil analisis deskriptif data motivasi peserta didik SMA di Kecamatan Bangli dalam mengikuti pembelajaran Pendidikan Jasmani, Olahraga dan Kesehatan secara daring adalah sebagai berikut:

Tabel 1. Deskripsi Analisis Hasil Penelitian Data Motivasi SMA Negeri 1 Bangli

\begin{tabular}{cccccc}
\hline No & Data & Minimum & Maksimum & Rata-rata & Standar Deviasi \\
\hline 1 & Pengetahuan & 5 & 8 & 6,36 & 0,99 \\
2 & Perhatian & 3 & 8 & 6,03 & 0,92 \\
3 & Minat & 4 & 12 & 9,68 & 1,33 \\
4 & Guru & 3 & 8 & 6,69 & 0,98 \\
5 & Teman & 3 & 8 & 5,12 & 1,07 \\
6 & Sarana prasarana & 3 & 8 & 6,16 & 1,51 \\
7 & Orang tua & 4 & 8 & 6,57 & 1,11 \\
\hline
\end{tabular}


Kemudian untuk hasil analisis deskriptif data motivasi peserta didik SMA Negeri 2 Bangli mengikuti pembelajaran Pendidikan Jasmani, Olahraga dan kesehatan dalam pembelajaran daring adalah sebagai berikut:

Tabel 2. Deskripsi Analisis Hasil Penelitian Data Motivasi SMA Negeri 2 Bangli

\begin{tabular}{|c|c|c|c|c|c|}
\hline No & Data & Minimum & Maksimum & Rata-rata & Standar Deviasi \\
\hline 1 & Pengetahuan & 2 & 8 & 6,03 & 1,36 \\
\hline 2 & Perhatian & 2 & 8 & 5,78 & 1,52 \\
\hline 3 & Minat & 3 & 12 & 8,95 & 2,19 \\
\hline 4 & Guru & 3 & 8 & 5,97 & 1,76 \\
\hline 5 & Teman & 2 & 8 & 4,90 & 1,28 \\
\hline 6 & $\begin{array}{c}\text { Sarana } \\
\text { prasarana }\end{array}$ & 3 & 8 & 5,90 & 1,54 \\
\hline 7 & Orang tua & 2 & 8 & 6,25 & 1,64 \\
\hline
\end{tabular}

Motivasi Peserta Didik SMA Negeri 1 Bangli pada Pembelajaran PJOK dalam Pembelajaran Daring

Dalam penelitian ini data motivasi peserta SMA Negeri 1 Bangli mengikuti pembelajaran Pendidikan Jasmani, Olahraga dan Kesehatan dalam pembelajaran daring dianalisis menggunakan teknik statistik deskriptif dengan teknik perhitungan menggunakan persentase.

Data dalam penelitian ini dikategorikan menjadi 5 yaitu: sangat tinggi, tinggi, sedang, rendah, dan sangat rendah. Data yang dikategorikan tersebut dibuat dengan berdasarkan mean ideal, dan standar deviasi ideal yang merupakan hasil perhitungan deskriptif. Motivasi peserta didik SMA Negeri 1 Bangli mengikuti pembelajaran Pendidikan Jasmani, Olahraga dan Kesehatan dalam pembelajaran daring diukur menggunakan angket yang berisi 30 butir pertanyaan, dari hasil analisis statistik deskriptif yang telah dilakukan diperoleh mean ideal sebesar 44,50 median sebesar 47,00 modus sebesar 49,00 dan standar deviasi ideal sebesar 3,17 . Distribusi pengkategorian dapat dilihat sebagai berikut:

Tabel 3. Motivasi Peserta Didik SMA Negeri 1 Bangli Mengikuti Pembelajaran PJOK dalam Pembelajaran Daring

\begin{tabular}{cccc}
\hline RANGE & KATEGORI & FREKUENSI & $\%$ \\
\hline $\mathrm{X}>49,25$ & $\mathrm{ST}$ & 37 & 31,09 \\
$46,08<\mathrm{X}<49,25$ & $\mathrm{~T}$ & 26 & 21,85 \\
$42,92<\mathrm{X}<46,08$ & $\mathrm{~S}$ & 28 & 23,53 \\
$39,75<\mathrm{X}<42,92$ & $\mathrm{R}$ & 20 & 16,81 \\
$39,75<\mathrm{X}$ & $\mathrm{SR}$ & 8 & 6,72 \\
TOTAL & & $\mathbf{1 1 9}$ & $\mathbf{1 0 0}$ \\
\hline
\end{tabular}

Apabila dilihat dari data jumlah peserta didik yang muncul pada setiap kategori, maka dapat dikategorikan bahwa motivasi peserta didik SMA Negeri 1 Bangli mengikuti pembelajaran Pendidikan Jasmani, Olahraga dan
Kesehatan dalam pembelajaran daring berada pada kategori sangat tinggi.

Data dari hasil analisis motivasi peserta didik SMA Negeri 1 Bangli mengikuti pembelajaran Pendidikan Jasmani, Olahraga dan Kesehatan dalam 
pembelajaran daring dapat dilihat pada gambar berikut:

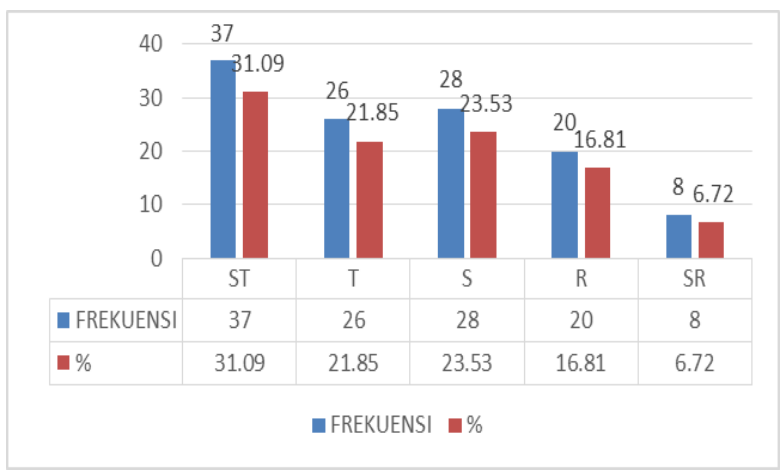

Gambar 1 Grafik Motivasi Peserta Didik SMA Negeri 1 Bangli Mengikuti Pembelajaran PJOK dalam Pembelajaran Daring

\section{Motivasi Peserta Didik SMA Negeri 2 Bangli pada Pembelajaran PJOK dalam Pembelajaran Daring \\ Dalam penelitian ini data motivasi} peserta SMA Negeri 2 Bangli mengikuti pembelajaran Pendidikan Jasmani,
Olahrga dan Kesehatan dalam pembelajaran daring dianalisis menggunakan teknik statistik deskriptif dengan teknik perhitungan menggunakan persentase. Data dalam penelitian ini dikategorikan menjadi 5 yaitu: sangat tinggi, tinggi, sedang, rendah, dan sangat rendah. Data yang dikategorikan tersebut dibuat dengan berdasarkan mean ideal, dan standar deviasi ideal yang merupakan hasil perhitungan deskriptif. Motivasi peserta didik SMA Negeri 2 Bangli mengikuti pembelajaran Pendidikan Jasmani, Olahraga dan Kesehatan dalam pembelajaran daring diukur menggunakan angket yang berisi 30 butir pertanyaan, dari hasil analisis statistik deskriptif yang telah dilakukan diperoleh mean ideal sebesar 38,00 median sebesar 43,00 modus sebesar 56,00 dan standar deviasi ideal sebesar 6.00. Distribusi pengkategorian dapat dilihat sebagai berikut:

Tabel 4. Motivasi Peserta Didik SMA Negeri 2 Bangli Mengikuti Pembelajaran PJOK dalam Pembelajaran Daring

\begin{tabular}{|c|c|c|c|}
\hline RANGE & KATEGORI & FREKUENSI & $\%$ \\
\hline$X>47,00$ & ST & 51 & 37,50 \\
\hline $41,00<X<47,00$ & $\mathrm{~T}$ & 26 & 19,12 \\
\hline $35,00<X<41,00$ & $S$ & 33 & 24,26 \\
\hline $29,00<X<35,00$ & $\mathrm{R}$ & 25 & 18,38 \\
\hline $29,00<X$ & SR & 1 & 0,74 \\
\hline \multicolumn{2}{|c|}{ TOTAL } & 136 & 100 \\
\hline
\end{tabular}

Apabila dilihat dari data jumlah peserta didik yang muncul pada setiap kategori, maka dapat dikategorikan bahwa motivasi peserta didik SMA Negeri 2 Bangli mengikuti pembelajaran Pendidikan Jasmani, Olahraga dan Kesehatan dalam pembelajaran daring berada pada kategori sangat tinggi.

Data dari hasil analisis motivasi peserta didik SMA Negeri 2 Bangli mengikuti pembelajaran Pendidikan Jasmani, Olahraga dan Kesehatan dalam pembelajaran daring dapat dilihat pada gambar berikut: 


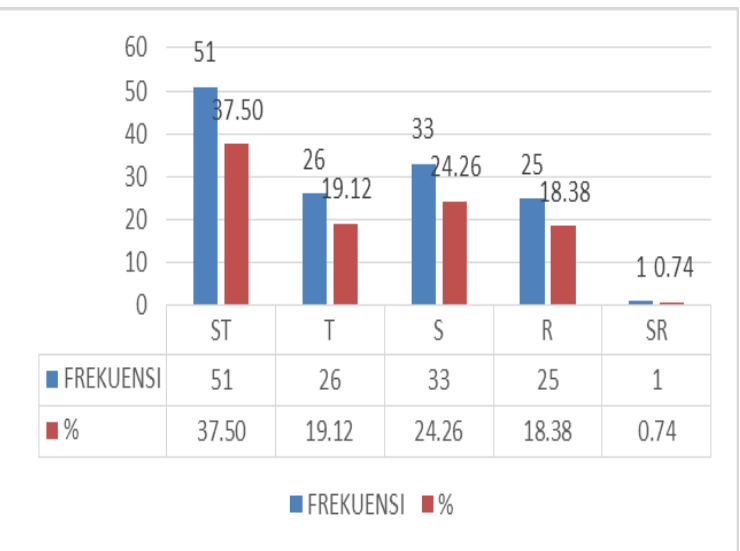

Gambar 2 Grafik Motivasi Peserta Didik SMA Negeri 2 Bangli Mengikuti

Pembelajaran PJOK dalam Pembelajaran Daring

\section{Pembahasan}

Motivasi Peserta Didik SMA di Kecamatan Bangli pada Pembelajaran PJOK dalam Pembelajaran Daring

Penelitian ini bertujuan untuk mengetahui seberapa besar motivasi yang dimiliki peserta didik SMA di Kecamatan Bangli mengikuti pembelajaran PJOK dalam pembelajaran daring, pengambilan data dalam penelitian ini dilaksanakan dengan menggunakan angket yang dibuat di google form dan analisis data dilakukan secara deskriptif kuantitatif.

Hasil data motivasi peserta didik SMA di Kecamatan Bangli yang telah dianalisis menunjukan bahwa motivasi peserta didik SMA di Kecamatan Bangli dalam mengikuti pembelajaran Pendidikan Jasmani, Olahraga dan Kesehatan secara daring yaitu sebanyak 105 peserta didik atau 41,18\% peserta didik yang memiliki motivasi sangat tinggi, sebanyak 71 peserta didik atau $27,84 \%$ peserta didik yang memiliki motivasi tinggi, sebanyak 52 peserta didik atau $20,39 \%$ peserta didik yang memiliki motivasi sedang, sebanyak 26 peserta didik atau 10,20\% peserta didik yang memiliki motivasi rendah, dan 1 peserta didik atau $0,39 \%$ peserta didik yang memiliki motivasi sangat rendah.
Dari data motivasi yang telah dianalisis, hasil analisis menunjukan bahwa motivasi peserta didik SMA di Kecamatan Bangli mengikuti pembelajaran Pendidikan Jasmani, Olahraga dan Kesehatan dalam pembelajaran daring berada dalam kategori sangat tinggi..

\section{PENUTUP \\ Simpulan}

Berdasarkan kesimpulan di atas, adapun saran yang dapat diberikan adalah sebagai berikut:

1. Bagi Peserta Didik

Menjadikan masukan dan sekaligus sebagai pemacu bagi peserta didik agar dapat lebih mengembangkan diri dalam mengikuti proses pembelajaran PJOK secara daring sehingga dapat meningkatkan pengetahuan, keterampilan diri mampu berprestasi walaupun belajar dari rumah.

2. Bagi Sekolah dan Guru

a) Sekolah agar mampu untuk memfasilitasi proses pembelajaran daring seperti dengan memberikan kuota internet secara gratis kepada peserta didik. Sehingga proses pembelajaran daring dapat berjalan dengan optimal.

b) Guru diharapkan mampu untuk mengkemas materi pembelajaran PJOK dengan baik dalam proses pembelajaran daring, sehingga membuat peserta didik menjadi termotivasi dalam mengikuti pembelajaran PJOK secara daring.

3. Bagi Peneliti

1. Peneliti selanjutnya diharapkan untuk mampu melaksanakan penelitian dengan meminimalisir keterbatasan waktu, biaya, dan kemampuan berfikir serta kemampuan bekerja agar tercapainya penelitian yang lebih sempurna.. 


\section{DAFTAR PUSTAKA}

Arimbawa, I G A., Budaya Astra I Kt., dan Satyawan I Md. 2017. "Pengaruh Penerapan Model Pembelajaran Kooperatif Tipe STAD Berbantuan Media Gambar Terhadap Hasil Belajar Teknik Dasar Passing Sepak Bola". Terdapat pada https://ejournal.undiksha.ac.id/index. php/JJP/article/view/11340. (diakses pada 25 Oktober 2019).

Ariffudin, David Hareva dan Sasmita Christina Yuli Artati. 2016. "Penerapan Model Pembelajaran Kooperatif Tipe Team Games Tournament (TGT) Untuk Meningkatkan Efektivitas Pembelajaran Passing Dalam Permainan Sepak Bola”. Terdapat pada

https://jurnalmahasiswa.unesa.ac.id/ index.php/jurnal-pendidikanjasmani/article/view/18772. (diakses pada 23 Oktober 2019).

Arikunto, Suharsimi. 2014. Prosedur Penelitian Suatu Pendekatan Praktik. Jakarta: Rineka Cipta.

Anggreni, Sri. 2018. "Minat dan Motivasi Berpretasi Peserta Didik Pada Ekstrakulikuler Olahraga di SMP Negeri 7 Singaraja". Fakultas Olahraga dan Kesehatan. Universitas Pendidikan Ganesha.

Gozali, Imam. Kartiko, Dwi Cahyo. 2019. "Survei Tingkat Pengetahuan Guru PJOK Tentang Pertolongan Pertama dan Pencegahan Cedera Olahraga di SMA/SMK seKecamatan Krembung". Terdapat

\section{pada}

https://jurnalmahasiswa.unesa.ac.id/ index.php/jurnal-pendidikan-

jasmani/article/view/27466. (diakses pada 22 Juli 2020).

Hendri, Gus dan Aziz, Ishak. 2020. "Motivasi Siswa Dalam Proses Pembelajaran Pendidikan Jasmani Olahraga Kesehatan". Terdapat pada

http://patriot.ppj.unp.ac.id/index.php/ patriot/article/view/533. (diakses pada 28 Juli 2020).

Jayul, Achmad dan Irwanto, Edi. 2020. "Model Pembelajaran Daring Sebagai Alternatif Proses Kegiatan Belajar Pendidikan Jasmani di Tengah Pandemi Covid-19". Terdapat pada https://ojs.ikippgribali.ac.id/index.ph p/jpkr/article/view/689. (diakses pada 09 Agustus 2020).

Kanca, I Nyoman. 2010. Metode Penelitian Pendidikan Jasmani dan Rekreasi. Singaraja: Universitas Pendidikan Ganesha.

Satyawan, I Made. 2011. Buku Ajar Belajar dan Pembelajaran Dalam Penjasorkes. Singaraja: Universitas Pendidikan Ganesha.

Sardiman A.M. 2008. Interaksi \& Motivasi Belajar Mengajar. Jakarta: PT Raja Grafindo Persada.

Sugiyono. 2006. Metode Penelitian Administrasi Dilengkapi dengan Metode R\&d. Bandung: CV Alfabeta. 
Jurnal Ilmu Keolahragaan Undiksha p-ISSN : 2613-9693 | e-ISSN : 2613-9685 Volume 8 Nomor 3 Tahun 2020

Trianto. 2010. Mendesain Model Penelitian, Skripsi, dan Artikel)". Pembelajaran Inovatif Progresif. Jakarta: Perpustakaan Nasional.

Singaraja: Universitas Pendidikan Ganesha

Wendra, I Wayan. 2019. "Penulisan Karya Ilmiah (Penulisan Proposal 